\title{
Tajne spotkania członków Rady Ligi Narodów w świetle dokumentacji Archivès de la Société des Nations w Genewie
}

Liga Narodów była pierwszą w dziejach organizacją międzynarodową, której głównym celem było położenie tamy wojnom poprzez rozbrojenie i rozwój współpracy między cywilizowanymi państwami. Jej powstanie wymuszone na mocarstwach europejskich przez prezydenta Stanów Zjednoczonych T. Woodrowa Wilsona, było precedensem w trwających poszukiwań lepszego, bardziej sprawiedliwego ułożenia stosunków politycznych i społecznych świata. Eksperyment z Ligą Narodów, grupującą ponad pięćdziesiąt państw ze wszystkich kontynentów towarzyszył cywilizacji przez cały okres międzywojenny. Zakres spraw, które były rozpatrywane lub tylko przewijały się przez organy i agendy Ligi Narodów był ogromny, o czym m.in. świadczy spuścizna archiwalna przekraczająca dwa kilometry akt ${ }^{1}$.

Sukcesy i porażki LN były paralelne do ewolucji sytuacji międzynarodowej tego czasu. Także na jej forum widoczna była dominacja mocarstw europejskich (wobec nieobecności Stanów Zjednoczonych oraz do 1934 r. ZSRR). To one zawarowały sobie głos decydujący poprzez ustanowienia tzw. stałych miejsc w Radzie Ligi. Zajmowały je Francja, Japonia, Wielka Brytania i Włochy (1919-1937), w latach 1926-1933 także Niemcy oraz ZSRR (1934-1939). Rada na równi ze Zgromadzeniem wszystkich członków, zajmowała się ogółem

${ }^{1}$ Archives de la Société des Nations 1919-1946. Répertoire Général 1919-1946. Genève sd., vol. 1-3. Ogólna charakterystyka archiwum Ligi i ONZ zob.: B. Blukacz-Louisfert, P. Le Loarer, Les archives de la Société des Nations et des Nations Unies: sources de première importance pour l'histoire des relations internationales au XXe siècle, w: 8e Conférence internationale des éditeurs de documents diplomatiques: des états et de l'ONU, red. Gabriel Robin, Publisher Bruxelles [etc.], Peter Lang, 2008, s. 321-334. Jeśli za podstawę wziąć opublikowane w tym tomie teksty (około czterdziestu), pokazujące dorobek naukowy oraz narodowy kontekst stosunków międzynarodowych „wielkich” $\mathrm{i}$ „małych” tego świata, to taki kraj, jak Polska, nie istnieje. 
spraw dotyczących działalności Ligi lub pokojem na świecie. Tak szeroko zakreślone kompetencje powodowały, że o tzw. niestałe miejsca w Radzie trwały niekończące się boje. Niejednokrotnie miały one dramatyczny przebieg, jak przy okazji wstępowania Niemiec do Ligi w 1926 r. Sprzeciw lub niechęć w sprawie przyznawania stałych miejsc Brazylii i Hiszpanii skłoniły je do wystąpienia z Ligi. Od podobnych gróźb nie stroniły również Polska i Chiny².

Nie lekceważąc motywacji o charakterze politycznym i prestiżowym, należy w tym tekście uwypuklić szczególną rolę poufnych, tajnych narad i spotkań, w końcu też „wymiany zdań” członków Rady, kiedy to wykuwały się lub wręcz były ustalone rozwiązania prezentowane następnie podczas "prywatnych" lub "publicznych” sesji Rady LN. Znaczenie tej dokumentacji archiwalnej dla pokazania "kuchni” tych negocjacji oraz poznania polityki poszczególnych państw reprezentowanych w Radzie, jest bezdyskusyjne. Poza wszystkim wyziera z nich prawda, znana zresztą w polityce od wieków, że dominuje interes własny, aczkolwiek w tym konkretnym przypadku był on przyodziany w "ligowe szaty". Tajne spotkania członków Rady to zrazu rozwiązanie doraźne, mające na celu uzgodnienia wspólnego, kompromisowego stanowiska przede wszystkim w kwestiach personalnych. Nie nadawano im rozgłosu, wszelkie bowiem spotkania tajne kłóciły się z filozofią Ligi Narodów, wyrażoną także w preambule do Paktu, gdzie mówi się o „utrzymywaniu jawnych stosunków międzynarodowych"3

Zgodnie z tym wskazaniem, spotkania członków Rady powinny mieć publiczny charakter. Oznaczało to możliwość uczestniczenia w obradach, w charakterze gości przedstawicieli wszystkich członków Ligi, a także dziennikarzy i innych osób zainteresowanych pracami Ligi lub omawianymi podczas danej sesji sprawami. Zabiegi o miejsce na "galerii" były tym intensywniejsze, im ważniejsze kwestie były omawiane. Liczba obserwatorów była zawsze reglamentowana.

Często z różnych powodów, także praktycznych, publiczne sesje Rady były poprzedzane "spotkaniami prywatnymi” (séances privées, Private Meetings), podczas których starano się uzgodnić stanowiska i wypracować formułę możliwą do przyjęcia przez wszystkich (w sprawach merytorycznych w Radzie LN obowiązywała zasada jednomyślności). Stopniowo coraz bardziej widoczną rolę odgrywały spotkania tajne. Od „prywatnych” różniły się tym, że ich przebieg, ewentualne wyniki (w tym protokoły z dyskusji) pozostawały tajne. Tym bardziej stroniono od rozgłosu, aczkolwiek samego faktu

2 Por. m.in.: H. Korczyk, Przyjęcie Niemiec i Polski do Rady Ligi Narodów w 1926 roku, Wrocław, Warszawa 1986; Ch. Leuchars, Brazil and the League Council Crisis of 1926, „Diplomacy \& Statecraft", Dec. 2001, vol. 12/4, s. 123 i n.; J. Wintzer, Deutschland und der Völkerbund 1918-1926, Paderborn etc. 2006; S. Sierpowski, Gra o Niemcy. Międzynarodowy rezonans wejścia Niemiec do Ligi Narodów w 1926 r., w: Repozytorium Uniwersytetu im. Adama Mickiewicza (AMUR).

${ }^{3}$ Więcej zob. S. Sierpowski, Narodziny Ligi Narodów, Poznań 1984. 
spotkań nie skrywano4. Zwyczajowo i najczęściej członkowie Rady spotykali się $\mathrm{W}$ gabinecie Sekretarza Generalnego.

Protokoły z tajnych spotkań Rady stanowią stosunkowo niewielką, wręcz ułamkową część spuścizny Ligi Narodów. Nie jest to materiał, podobnie jak całe archiwum Ligi, opracowany pod względem archiwalnym $^{5}$. W poszczególnych kartonach (i dalej teczkach spraw założonych $\mathrm{w}$ czasie działalności Ligi) znajdują się też wtórniki i kopie, także powielaczowe. Wszechobecna i dominująca często frazeologia powodowała inflacje słowa pisanego, udostępnianego $\mathrm{w}$ obu oficjalnych językach LN (angielskim i francu-

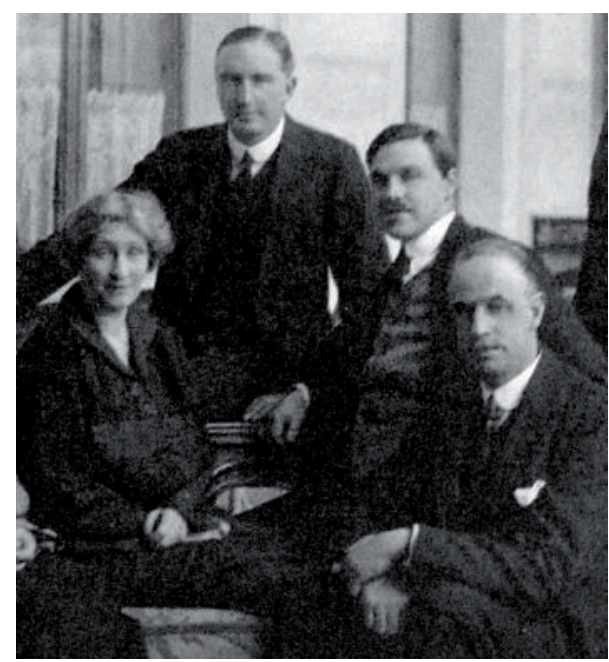

Il. 1. Eric Drummond z najbliższymi współpracownikami: za Sekretarzem Generalnym F.P. Walters dyr. Biura, powyżej mjr A. Buxton, $\mathrm{z}$ lewej p. J. Howard skim) oraz niejednokrotnie także w niemieckim czy hiszpańskim. Ta ogromna dokumentacja odzwierciedla bardzo szeroki zakres aktywności tzw. „instytucji genewskiej”. Od wielkiej polityki - rozbrojenia, bezpieczeństwa zbiorowego, poprzez sprawy społeczne (higiena, niewolnictwo, handel kobietami itp.), po ważne po dziś regulacje dotyczące znaków drogowych, ulicznej sygnalizacji świetlnej, korytarzy dla samolotów, reformy celnej, paszportów dla bezpaństwowców itd.

Wszystkie te kwestie przewijały się, aczkolwiek z różną intensywnością, podczas tajnych spotkań członków Rady LN. Listę protokołów z tych kontaktów otwiera posiedzenie z 25 lutego 1921 r. (nazywanych jednak Private Meeting of Council), a zamyka sprawozdanie ze spotkania 9 grudnia $1939 \mathrm{r}$. związane z procedurą usunięcia ZSRR z Ligi. W sumie w ramach prac Rady LN odbyło się około 170 tajnych spotkań ${ }^{6}$. Z ich policzeniem mieli pewne kło-

4 Annuaire de la Société des Nations 1919-1927, Genève 1927, s. 5, o tajnych spotkaniach wspomina się tylko raz, przy okazji charakterystyki pracy Ligi. W kolejnych tomach Annuaire także poprzestawano na zdawkowym stwierdzeniu, że Rada odbywa też tajne spotkania, w których biorą udział członkowie Rady oraz Sekretarz Generalny.

${ }^{5}$ Można mówić o częściowym opracowaniu materiałów Komisji Mandatowej, co sprowadza się do ponumerowania stron, zob. „Archivès de la Société des Nations» (cyt. dalej ASDN), r. 2344-2346.

${ }^{6}$ Mam świadomość jedynie orientacyjnego charakteru podanej liczby. Przekonujący jest przykład dotyczący grudnia $1925 \mathrm{r}$. W jednym z wykazów (Procès - verbaux des séance secrètes du Conseil - 25 février 1921 - 15 décembre 1928) pod pozycją 20. zapisano: „Séance secrètes, dec. 1925". W innym wykazie sporządzonym według odręcznej notki przez szefa archiwum Ligi 

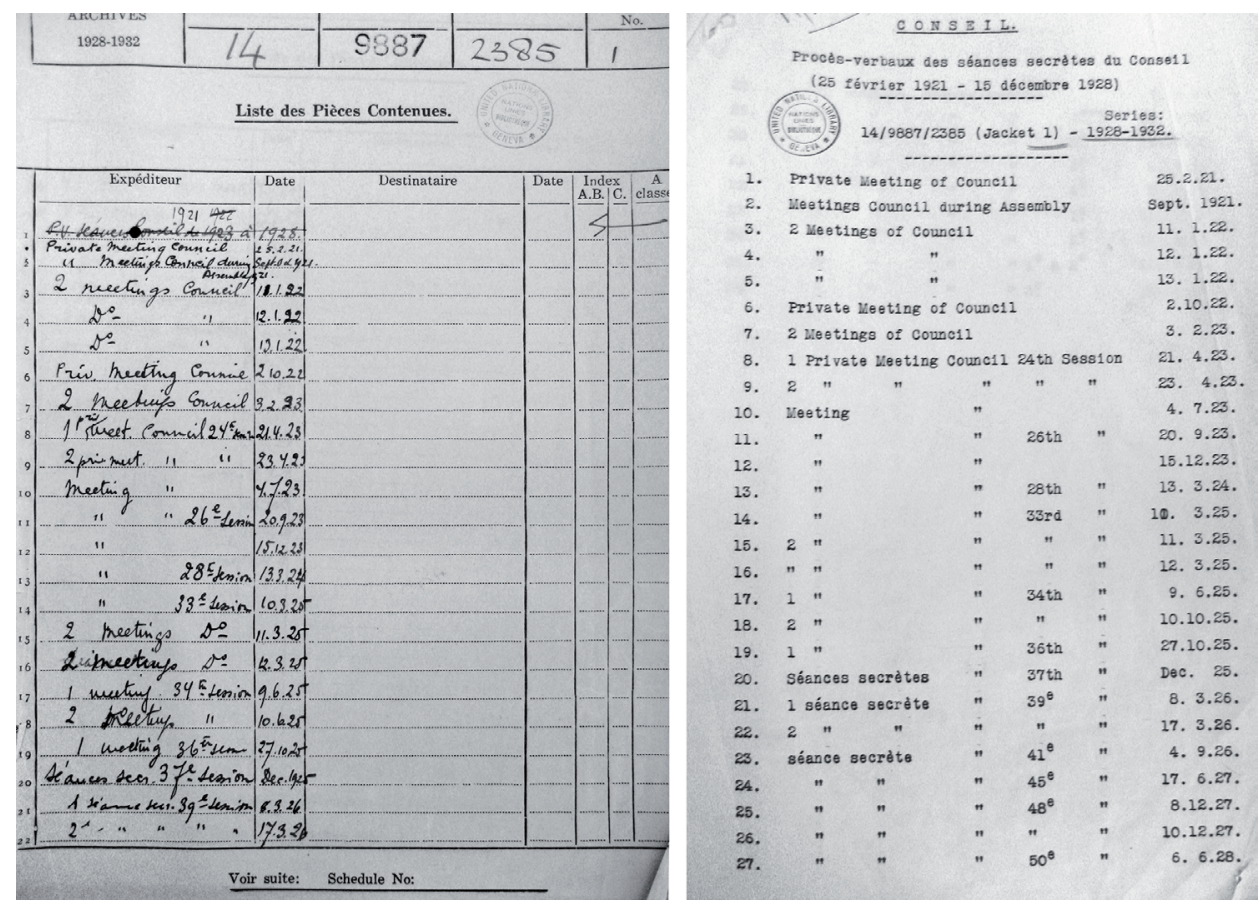

Il. 2. Teczka z rejestrem prywatnych i tajnych protokółów Rady LN za lata 1921-1926 oraz sporządzone na tej podstawie zestawienie tajnych spotkań członków Rady LN za okres 25 lutego 1921 - 15 grudnia $1928 \mathrm{r}$.

poty już urzędnicy Ligi, tak Sekretariatu, jak i archiwum. Tym bardziej jest to trudne obecnie bez analizy każdego ze spotkań, które ma w nagłówku protokołu „Private Meeting of Council”. Tak zapisano pierwszą pozycję rejestru „tajnych spotkań" Rady, obejmującego protokoły z lat 1921-19287. Spis ten powstał przez przepisanie wykazu umieszczonego na skoroszycie (teczce) zawierającym protokoły z tego czasu. Rejestr sporządzono bez weryfikacji ze stanem faktycznym, gdyż nie uwzględnia on np. spotkania Rady 3 października 1921 r., które zapisano jako: spotkania Rady podczas Zgromadzenia, wrzesień 1921 r. (na teczce jest "prywatne spotkania Rady" - zob. ilustracje 2.).

Pewną komplikacją uwidocznioną powyżej, związaną z brakiem rozróżnienia między spotkaniami "prywatnymi” a "tajnymi”, łączyć należy z tym, że Rada działała przez wiele lat bez regulaminu. Interweniował $w$ tej sprawie de-

J. Vallery-Radota po wyjeździe sir Erica (a więc po 1933 r.) wykazano aż pięć spotkań tajnych 8, 9, 10, 12 i 14 grudnia 1925 r., oba wykazy ASDN, 14/985/1285; r. 6228 (zob. ilustr. 2 i 3).

7 ASDN, 14/9887/2383; r. 6228 (Couseil. Procès - verbaux des séances secrètes du Conseil (25 février 1921 - 15 décembre 1928); dok. bez daty, lecz ok. połowy 1929 r. 


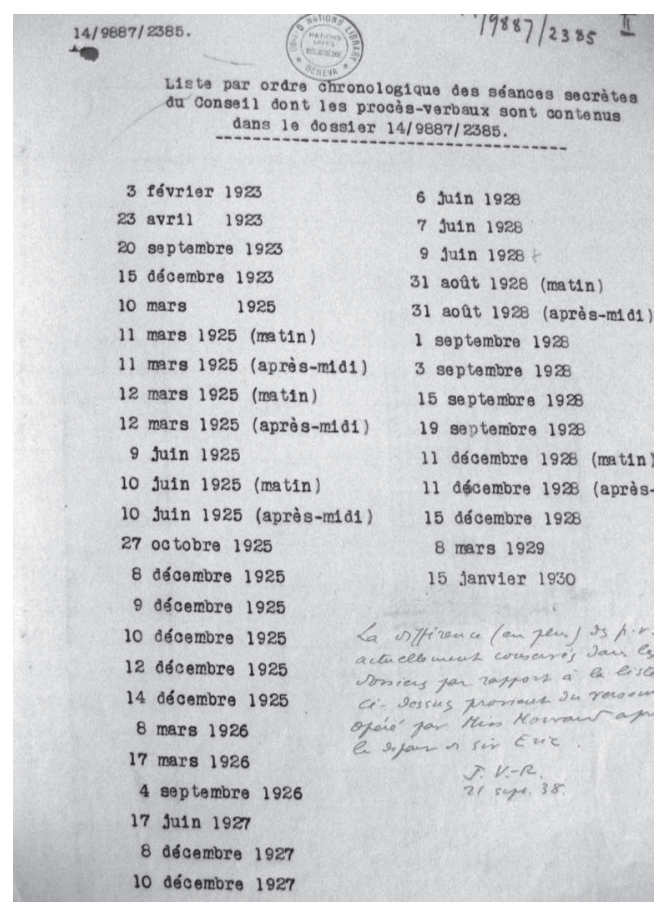

Il. 3. Rejestr tajnych spotkań członków Rady LN sporządzony po 1933 r. J. Valery-Radot odręcznie dopisał: „Różnica między p. v. aktualnie zachowanych w aktach a listą powyżej pochodzi ze zbioru wykonanego przez Miss Hovard po wyjeździe sir Erica. J. V. -R.21 wrz. 38". legat Norwegii min. Carl Joachim Hambro, ale dopiero 27 września 1932 r. Swój głos łączył on z dyskutowanym właśnie ustąpieniem sir Erica Drummonda ze stanowiska sekretarza generalnego. Wielkie doświadczenie rezygnującego $\mathrm{z}$ pracy $\mathrm{w}$ sekretariacie urzędnika związane z funkcjonowaniem Rady powinno - według min. Hambro - zostać ujęte $\mathrm{w}$ formie odpowiedniego dokumentu. Polityk norweski "słyszał" o takim dokumencie opracowanym w 1920 r., ale go nie zna. Eric Drummond potwierdził fakt istnienia regulaminu, który jednak opracowany przez prawników nie znalazł w praktyce zastosowania. Ponowione przez min. Hambro oczekiwanie na opracowanie stosownego regulaminu Norweg opatrzył sugestią, aby dokument ten zostal przygotowany przez ludzi „,z pewnym doświadczeniem politycznym, a nie tylko prawniczym"s.

$Z$ realizacją tego zadania nie spieszono się. Jednym z powodów była ogólna niechęć do tajnych spotkań ze strony państw $w$ tym gronie nieobecnych. Kontestowali je również zwolennicy „wyidealizowanej” Ligi, oraz - z drugiej strony - jej krytycy i wrogowie. Ze zrozumiałych powodów wokół tajnych spotkań Rady toczył się nieustanny kontredans domysłów i plotek, zwłaszcza kiedy spotkanie kończyło się odroczeniem dyskutowanej kwestii, aby dać „czas na refleksję". Atmosferę zaciekawienia podgrzewały spotkania "nocne" ${ }^{\prime \prime}$ czy też ponawiane tego samego dnia - rano (zwykle o 10.00) i wieczorem (nawet o 19.30). Dotyczyło

8 ASDN, 14/9885/2385, R: 6228, First Secret Meeting, September 27th, 1932.

9 Z. Rudnicki, Systemowe i doktrynalne determinanty w praktyce Ligi Narodów, Kraków 2005, s. 167, pisze o "nocnej sesji Rady", ale nie precyzuje, o jaką godzinę chodzi; za "nocną" sesję Rady (ale nie tajną) uznać należy spotkanie o 22.3010 grudnia 1927 r., jako efektu swoistego „szantażu” Józefa Piłsudskiego, oczekującego od premiera Voldemarasa stwierdzenia w obecności Rady, że Polska i Litwa nie są w stanie wojny, zob. S. Sierpowski, Piłsudski w Genewie, Poznań 1989, s. 111. 
to sytuacji ekstremalnych, kiedy Rada była pod szczególnym ciśnieniem bieżących wydarzeń. Odnosiło się to zwłaszcza do przełomu lat 20. i 30., kiedy na światowy kryzys gospodarczy nałożyły się konflikty zbrojne między państwami Ameryki Łacińskiej (Boliwia - Paragwaj), Azji (Japonia - Chiny), spory poprzedzające konferencję rozbrojeniową, a nadto rekonstrukcja Rady i Sekretariatu w związku z opuszczeniem Ligi przez Japonię i Niemcy oraz ustąpieniem Sekretarza Generalnego ${ }^{10}$.

Powyższy rejestr problemów uwypukla swoiste zapotrzebowanie na tajne spotkania Rady, które pojawiły się jako remedium na konflikty między państwami - członkami Ligi. Pierwotnie chodziło o ustalenia dotyczące spraw personalnych, zawsze wywołujących kontrowersje. Wiara, że "nasi" przedstawiciele w sekretariacie LN będą "pilnowali” ojczystych interesów w Genewie, była przemożna i powszechna. Problemów, które zasługiwały na rozpatrzenie $\mathrm{w}$ wąskim gronie, stopniowo przybywało. Pokazywane światu ewentualnych sporów (nierzadko o jawnie egoistycznym charakterze) podczas sesji prywatnych czy publicznych, godziło w budowany dopiero prestiż organizacji genewskiej. Problem sprowadzał się do tego, że w sesjach prywatnych Rady mogli uczestniczyć przedstawiciele państw-członków bezpośrednio zainteresowanych dyskutowaną sprawą, a także inni członkowie Ligi w charakterze obserwatorów. Liczba uczestników takiej sesji zwiększała się o zastępców, sekretarzy, tłumaczy ${ }^{11}$, co utrudniało dyskusję i pomnażało ryzyko "przecieków”, z którymi zresztą nigdy sobie nie poradzono. To był też jeden z argumentów na zawężenie liczby osób uczestniczących w spotkaniach, mających przygotować grunt dla sesji prywatnych i publicznych. W miejsce Private Meeting of Council pojawiło się określenie secret meeting. Po raz pierwszy widnieje ono w notatce Erica Drummonda ze spotkania 11 stycznia 1922 r., które było poświęcone nominacji członków Komisji Zarządzającej Saary ${ }^{12}$.

10 Sprawa oczekiwanej i spodziewanej dymisji sir Erica wywoływała różnie motywowany opór Rady, zatroskanej zwłaszcza trudnościami z wyłonieniem następcy. Do kwestii tej podczas tajnych sesji Rady w 1932 r. powracano kilkakrotnie. Odnotowuję w kontekście tytułu tej rozprawy, że na żadnym z kilku istniejących wykazów Secret Meetings nie ma spotkania z 20 maja 1932 r., które zaczęło się o 18.30 w gabinecie Sekretarza Generalnego i dotyczyło ogłoszenia jego dymisji. „Compte - rendu sommaire” liczy sześć stron w j. francuskim - ASDN, 14: 9887/2385, R: 6228 .

11 Oprócz oficjalnych tłumaczy Ligi, którzy przekładali każde wystąpienie na jeden z dwóch oficjalnych języków, min. Stresemann korzystał z przywileju posiadania osobistego tłumacza, którym był Paul Schmidt. Większość mówców występowała po francusku (w tym min. Beck, Raczyński, Benesz, przedstawiciele państw Ameryki Łacińskiej), co następnie było tłumaczone na angielski. Nieraz protokoły bywają w obu językach.

12 ASDN, 14/9887/2385; R. 6228; Notatka E. Drummonda bez nagłówka, January 11th 1922. Bez kruszenia kopii co do wagi pierwszego zapisu o spotkaniu tajnym należy odnotować, że parafowany przez E.D. protokół z 13 stycznia 1922 roku zaczyna się od słów „Rada odbyła tego wieczoru tajne spotkanie" - ASDN, 14/9887/2385; r. 6228, dok. bez nazwy, January 13th, 
Protokoły z pierwszych utajnionych spotkań nie precyzowały ich charakteru $\mathrm{w}$ tytule dokumentu. Widnieje tam np. Commentaires. Minutes, "notes” lub najczęściej Private Meeting of Council. Tytuł Séances secrète widnieje na protokołach poczynając od grudnia $1925 \mathrm{r} .{ }^{13}$ Wraz z wyborem Josepha Avenola na Sekretarza Generalnego w 1933 r. pojawia się nowe określenie dla tajnych spotkań członków Rady, nazywane dyskusją, wymianą opinii. Owo échange de vues aż do końca $1936 \mathrm{r}$. sąsiaduje z séance secrète, by następnie zdominować terminologię charakteryzującą te spotkania członków Rady. Odnotować zarazem trzeba, że na protokołach z owej dyskusji Sekretarz Generalny dopisywał własnoręcznie „,secrète"14.

Do tej terminologicznej niekonsekwencji dodać trzeba stwierdzenie widniejące w Regulaminie Rady przyjętym przez Zgromadzenie w 1937 r., że w ramach prywatnych sesji Rady (a więc bez publiczności i prasy) odbywają się także spotkania tajne. W takich przypadkach członkom Rady mogła towarzyszyć tylko jedna osoba, a Sekretarzowi Generalnemu „niezbędne minimum urzędników”. Jeśli jednak porządek prywatnych sesji mógł być za zgodą Rady opublikowany, to oświadczenia związane ze spotkaniami tajnymi mogli wydawać przewodniczący danej sesji Rady (w ramach której spotkanie miało miejsce) lub Sekretarz Generalny. Za ich zgodą uczestnicy échange de vues mogli też informować swoje rządy o treści spotkania, zważając na „interes Ligi Narodów, jak i uzasadnione pragnienie rządów do uzyskania w odpowiednim czasie informacji o generalnym kierunku prac Rady"15.

Ta ostatnia dyspozycja to próba przezwyciężenia niepisanej zasady, że treści tajnych spotkań członków Rady nie podlegają upowszechnieniu. Z fikcji takiego założenia zdawano sobie powszechnie sprawę, i to nie tylko kiedy czytano w porannych dziennikach wypowiedzi prezentowane na tajnym spotkaniu w dniu poprzednim. Sprawozdania, nierzadko bardzo dokładne, uczestnicy tajnych narad przekazywali do "swoich” stolic, zwłaszcza jeśli nie było w Genewie ministra spraw zagranicznych. Liczne ślady takiej aktywności informacyjno-dokumentacyjnej spotkamy w archiwach wszystkich państw aktywnych w polityce międzynarodowej. Dotyczy to także rządów nieobecnych aktualnie w Radzie.

1922.W cytowanej już książce Piłsudski w Genewie, s. 103 podaję (za przytoczonym wyżej zestawieniem, por. przyp. 6), że séances secrètes pojawiają się dopiero w grudniu 1925 r. Potwierdzić jedynie mogę, że istotnie tak w owym rejestrze jest, aczkolwiek błędnie!

${ }^{13}$ ASDN, 14/9887/2385; r. 6228 (Liste par ordre chronologique des séances secrètes du Conseil dont les procès-verbaux sont contenus dans le dossier 14/9887/2385; b.daty).

14 ASDN, 14/3543/1198; r. 6232, Procès - verbal provisoire d'une échange de vues (secrète) tenue à Genève le lundi 24 mai 1937, à 17 h. 15 (kursywą wyróżniono ręczny dopisek Sekretarza Generalnego Josepha Avenola).

${ }^{15}$ Le Conseil de la Société des Nations: Composition. Compétence. Procédure, Genève 1938, s. 65; przewodniczącym i sprawozdawcą Komisji opracowującej regulamin był Tytus Komarnicki, tamże, s. 110. 
Niejednokrotnie skrywanie treści wypowiedzi reprezentantów poszczególnych państw na forum Rady nie miało merytorycznego uzasadnienia. Nawet biorąc pod uwagę skłonność ówczesnych dyplomatów do dzielenia „włosa na czworo" (Liga Narodów była mimo wszystko zdominowana pragmatyką prawniczą), to i tak stanowiska poszczególnych państw były na ogół znane. Mimo tego dbano o zachowanie tajności nawet wówczas, kiedy pierwotnie godzono się na ujawnienie przebiegu dyskusji. Z sytuacją taką spotykamy się podczas trwających wiele miesięcy (sensu largo: wiele lat!) sporów wokół warunków przyjęcia Niemiec do Ligi. Oto bowiem podczas 17 czerwca 1926 r. sir Eric przypomniał członkom tajnego spotkania Rady powzięte przed rokiem postanowienie, że wszystkie raporty dotyczące rekonstrukcji Rady będą komunikowane wszystkim członkom Ligi. „W nowych warunkach" tej otwartości byli przeciwni nie tylko bezpośrednio zainteresowany przedstawiciel Hiszpanii (Quiñones de Leòn), ale także delegat Włoch Bonin-Langare. Uzgodniono jedynie treść ogólnego komunikatu, podkreślającego wagę spraw będących nadal przedmiotem pracy Rady i specjalnie wyłonionej tzw. komisji rekonstrukcji ${ }^{16}$.

Członkowie tej sesji Rady, świadomi ogromnego napięcia towarzyszącego planom istotnej zmiany składu Rady, woleli kontynuować praktykę utajnionych narad, chociaż stanowiska i oczekiwania takich państw, jak: Brazylia, Chiny, Hiszpania, Niemcy i Polska, były dobrze znane. Każde z tych państw, zgodnie z własnymi racjami i interesami, forsowało rozwiązania, wobec których pozostali uczestnicy sporów mieli niejednolity stosunek. Bywały jednak tajne spotkania członków Rady, które podejmowały sprawy „wstydliwe” dla pewnej grupy państw. Dotyczyło to zaległości finansowych państw-członków, którzy ociągali się z wniesieniem przypisanej im składki do wspólnej kasy. Dotyczyło to m.in. Francji. Jej przedstawiciel min. Gabriel Hanotaux tłumaczył powstałe zaległości za 1921 r. kłopotami operacyjnymi między bankami $^{17}$.

Przykładem uzasadniającym przydatność uzgodnień w ograniczonym, "godnym zaufania" gronie jest dyskusja towarzysząca wstąpieniu do Ligi jedynego de facto niepodległego państwa w Afryce - Etiopii. Od początku 1922 r. krążył po różnych agendach Ligi i organizacjach społecznych raport brytyjskiego Anti-Slavery Cociety, który kreślił nieprzyjazny obraz Etiopii jako ostatniej sadybie niewolnictwa w Afryce, a zapewne i na świecie ${ }^{18}$. Jednak rozwojem dyskusji w tym duchu nie były zainteresowane mocarstwa zasiadające

${ }^{16}$ ASDN, 14/9887/2358; r. 6228, Séance secrète du lundi, 8 mars 1925, à midi.

17 Tamże, dok. bez tytułu: sygnowano E.D. January 11th 1922.

18 A. Ribi, 'The Breath of a New Life'? British Anti-Slavery Activism and the League of Nations, w: Internationalism Reconfigured: Transnational Ideas And Movements Between The World Wars, red. D. Laqua 2011, s. 101 (eBook Academic Collection (EBSCOhost), Ipswich, MA. Accessed March 12, 2013). 
z miejscami stałymi w Radzie (które ostro rywalizowały o wpływy w Addis Abebie) oraz przedstawiciele członków z wyboru Zgromadzenia, jak Brazylia czy Chiny. Niewolnictwo lub zbliżone formy zależności były dość powszechne, także w takich innych państwach należących do Ligi, jak Liberia, Boliwia czy Peru. Wywołana przy okazji akcesji Etiopii dyskusja mogła dotknąć wcale nie marginalny w ówczesnym świecie system peonage - niewolnictwo za długi oraz pawning - niewolnictwo w efekcie zastawu lombardowego. Nie dotyczył on tylko państw arabskich, azjatyckich, afrykańskich czy latynoamerykańskich. Był on obecny także na Bałkanach i we Włoszech, gdzie funkcjonowała dzierżawa za połowę zbiorów, oraz w Stanach Zjednoczonych ${ }^{19}$. Dyskusja na tajnym spotkaniu członków Rady 4 lipca 1923 r., która poprzedzała formalną procedurę związaną z akcesem Etiopii do Ligi, pozwoliła na zminimalizowanie ryzyka niepożądanych aluzji. Na wniosek lorda Cecila raport Rady przedkładany Zgromadzeniu miał kończyć się pojednawczą formułą, że badania sytuacji wewnętrznej nie są zakończone i będą koordynowane przez Sekretariat Ligi z udziałem wszystkich zainteresowanych państ $w^{20}$.

Tajne spotkania członków Rady uzasadniano najczęściej koniecznością uwolnienia organów Ligi od sytuacji konfliktowych, w tym zwłaszcza sporów między państwami w związku z wyborami niestałych członków Rady. Nie mniejszą aktywność przejawiali członkowie LN w sprawie obecności „swoich" obywateli wśród pracowników Sekretariatu. W obu tych sprawach usatysfakcjonowanie oczekiwań formułowanych przez zdecydowaną większość członków Ligi było nierealne i niewykonalne. Chociaż liczba niestałych miejsc w Radzie systematycznie rosła (z 4 do 11 w 1939 r.), to u kresu Ligi aż 25 jej członków nie było w Radzie w ogóle reprezentowanych.

Nieco tylko większe pole manewru występowało w bojach dotyczących zatrudnienia w Sekretariacie. Dominacja brytyjsko-francuska była konsekwentnie kontestowana przez pozostałych stałych członków Rady (Włochów, Japończyków oraz po 1926 r. Niemców) i rzeszę niezadowolonych, którzy przywoływali różne argumenty, nieraz nawet zbyt niską płacę, co kontrastowało - np. w opinii delegata Brazylii - z kompetencjami kandydata do pracy w Sekretariacie oraz wysokimi kosztami utrzymania ${ }^{21}$.

Sekretarz Generalny i wspierający go „posesjonaci” salwowali się obietnicami, że w miarę wygasania kontraktów oczekiwania zasadnie niezadowolonych będą uwzględniane w atmosferze pełnej życzliwości, nieraz nawet uprzywilejowania... Niejednokrotnie przeszkodą w realizacji obietnic były

${ }^{19}$ W 1921 r. sąd w Covington (Georgia) skazał na dożywocie farmera i jego czarnego pomocnika winnych śmierci 11 „peonów”. Wyrok ten nie zniwelował zyskownego systemu, rozpowszechnionego zwłaszcza na Południu, mimo formalnego zakazu obowiązującego w Stanach Zjednoczonych od $1867 \mathrm{r}$.

${ }^{20}$ ASDN, 14/9887/2385; r. 6228, Notes on a secret Meeting..., July 4th. 1923.

21 Tamże, videmat z inicjałami E.D. January 13th. 1922; obszernie: F.F. Ranshofen-Wertheimer, The International Secretariat, Washington 1945, s. 241 i n. 


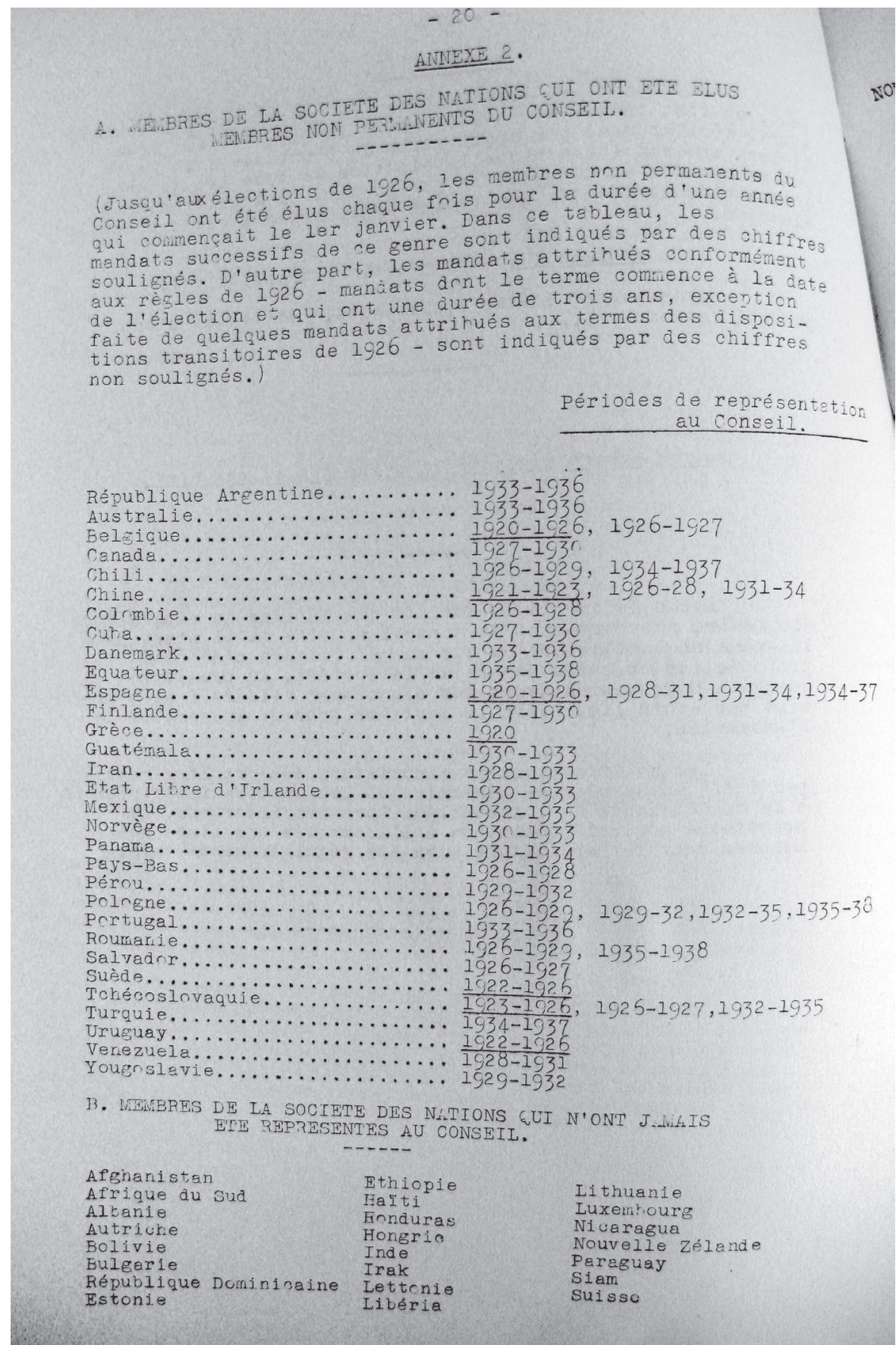

Il. 4. Rejestr niestałych członków Rady Ligi Narodów oraz państw w niej nieobecnych za lata 1920-1938 
konkursy, kiedy indziej proste zastępowanie urzędnika ustępującego obywatelem z tego samego kraju. Bywały jednak sytuacje szczególne, jak np. rezygnacja Jeana Moneta ze stanowiska zastępcy Sekretarza Generalnego i przeforsowanie na to miejsce Josepha Avenola - kolejnego Francuza, mającego już angaż w Sekretariacie. Podczas tajnego spotkania Rady 3 lutego 1923 r. zapobiegliwość delegata francuskiego René Vivaniani'ego napotkała niechęć włoskiego min. Antonio Salandry, który sugerował odłożenie decyzji do czasu efektywnego ustąpienia Moneta. Pożądaną zwłokę chciał wykorzystać na rozważenie dalej idących reorganizacji Sekretariatu, w którym Włosi nie byli właściwie reprezentowani. Delegat Japonii Minéitciro Adaci też widział potrzebę pogłębionej dyskusji na temat Sekretariatu, ale sugerował w konkretnej sytuacji uwzględnienie zasady „senioralności” oraz zasług już poniesionych dla Ligi. Argument ten podchwycili też James Balfour oraz Paul Hymans z Belgii, którzy wskazywali na dwuletnią już aktywność Avenola w Genewie, ocenianą jak najlepiej. Dominowało przekonanie, jak napisano $\mathrm{w}$ protokole, że w "obecnych warunkach” znalezienie odpowiedniego kandydata, który „zadowoli wszystkich członków Rady i większość obecnych na Zgromadzeniu, będzie trudne"22.

Min. Salandra nie był przekonany co do słuszności obranej procedury i wstrzymał się od głosu. Niemniej Rada, jako organ de facto decydujący $\mathrm{w}$ wielu istotnych sprawach personalnych, uchroniła się od pokazania istniejącego w jej wnętrzu konfliktu interesów. Poza wszystkim odosobnienie delegata Włoch, który w tym wypadku nie znalazł żadnego wsparcia wśród pozostałych siedmiu członków Rady, pozostaje wymowne ${ }^{23}$.

Powyższe pokazuje również, że zakulisowe przygotowania dotyczące decyzji personalnych były efektywne. $Z$ reguły też podczas tajnych spotkań członków Rady dochodziło do akceptacji wniosków kadrowych. Utrwaliła się też praktyka opiniowania wszystkich wniosków tego typu, także niebudzących kontrowersji. Przykładu dostarcza powołanie na stanowisko doradcy prawnego Sekretariatu Enrique Buero, profesora prawa międzynarodowego, delegata Urugwaju na 41. sesję Rady (2-7 września 1926 r.), osobę bardzo popularną „we wszystkich państwach Ameryki Łacińskiej”. Kandydatura, uzgodniona także w gronie państw „latynoskich”, których stanowisko prezentował Francesco Urrutia (Kolumbia), zyskała jednomyślne poparcie ${ }^{24}$.

Spotkanie powyższe zamknęło trwającą od września 1926 r. przerwę w tajnych spotkaniach członków Rady. Przerwę tę (zważywszy na raczej formalny charakter narady poświęconej nominacji prof. Buero) można przeciągnąć do 8 grudnia 1927 r., kiedy zajmowano się skargami Litwy na Polskę.

22 ASDN, 14/9887/2385; Note by the Secretary General, February 3th. 1923, Paris.

${ }^{23}$ Enrica Costa Bona (L'Italia e la Società delle Nazioni, Padova 2004) rywalizacji francusko-włoskiej nie eksponuje i tego drobnego incydentu nie odnotowała.

${ }^{24}$ ASDN, 14/9887/2385; Seance secrét..., 17 Juin 1927. 

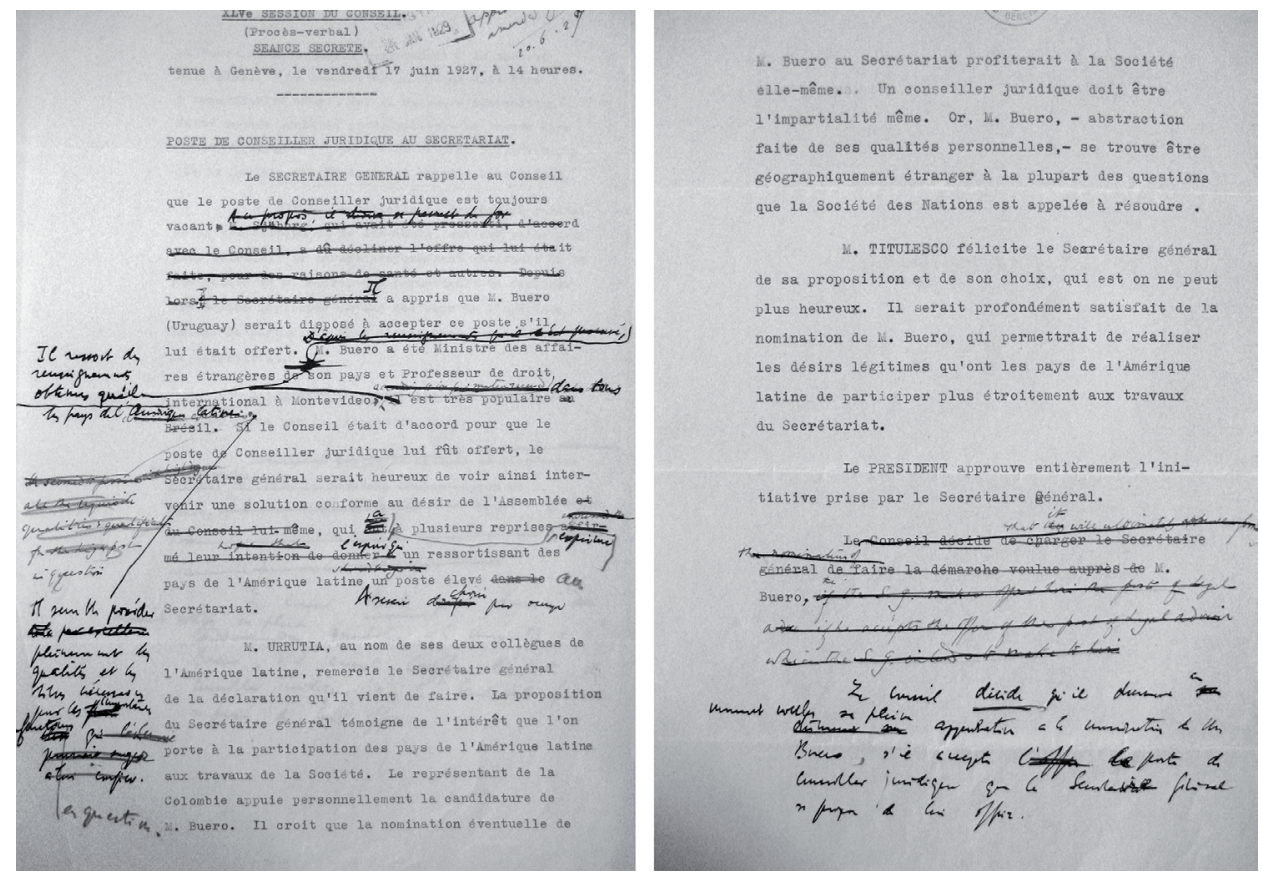

Il. 5. Pierwotny tekst protokołu tajnego spotkania członków Rady z interwencjami Sekretarza Generalnego

Spełnianą de facto rolę tajnych spotkań członków Rady przejęły tzw. tea partie. Bez rozgłosu, nierzadko w gabinecie Sekretarza Generalnego, spotykali się główni aktorzy genewskich sezonów politycznych - Aristide Briand, Austen Chamberlain i Gustaw Stresemann. Od września 1926 r., kiedy Niemcy znaleźli się w Lidze, liderzy polityczni z Francji, Wielkiej Brytanii i Niemiec uczestniczyli wspólnie w dziesięciu sesjach Rady i dwóch Zgromadzeniach. Za każdym razem rozniecało to falę spekulacji i pobudzało wyobraźnię polityków innych państw, w tym także pozostałych "lokarneńczyków”. Owe tea parties wypełniały więc częściowo funkcję tajnych spotkań członków Rady jako „ustawiające” przebieg dyskusji podczas sesji publicznych.

Mało znaczące $z$ merytorycznego punktu widzenia tajne spotkanie członków Rady w sprawie nominacji prof. Buero przykuwa uwagę z powodu sporządzonego wówczas protokołu. Reprodukowane poniżej ilustracje (nr 5 i 6) pokazują daleko idące ingerencje w tekst ze strony Sekretarza Generalnego. Zmiany dotyczyły jego wypowiedzi, w tym wprowadzenia frazy o popularności Buero „we wszystkich państwach Ameryki Łacińskiej” w miejsce wykreślonej Brazylii (Buero był z Urugwaju). Stosunkowo liczne zmiany wprowadzone ręką sir Erica spowodowały, że cały protokół - już ze zmianami - został przepisany. Nowa wersja protokołu nie ma jednak asygnaty Sekreta- 

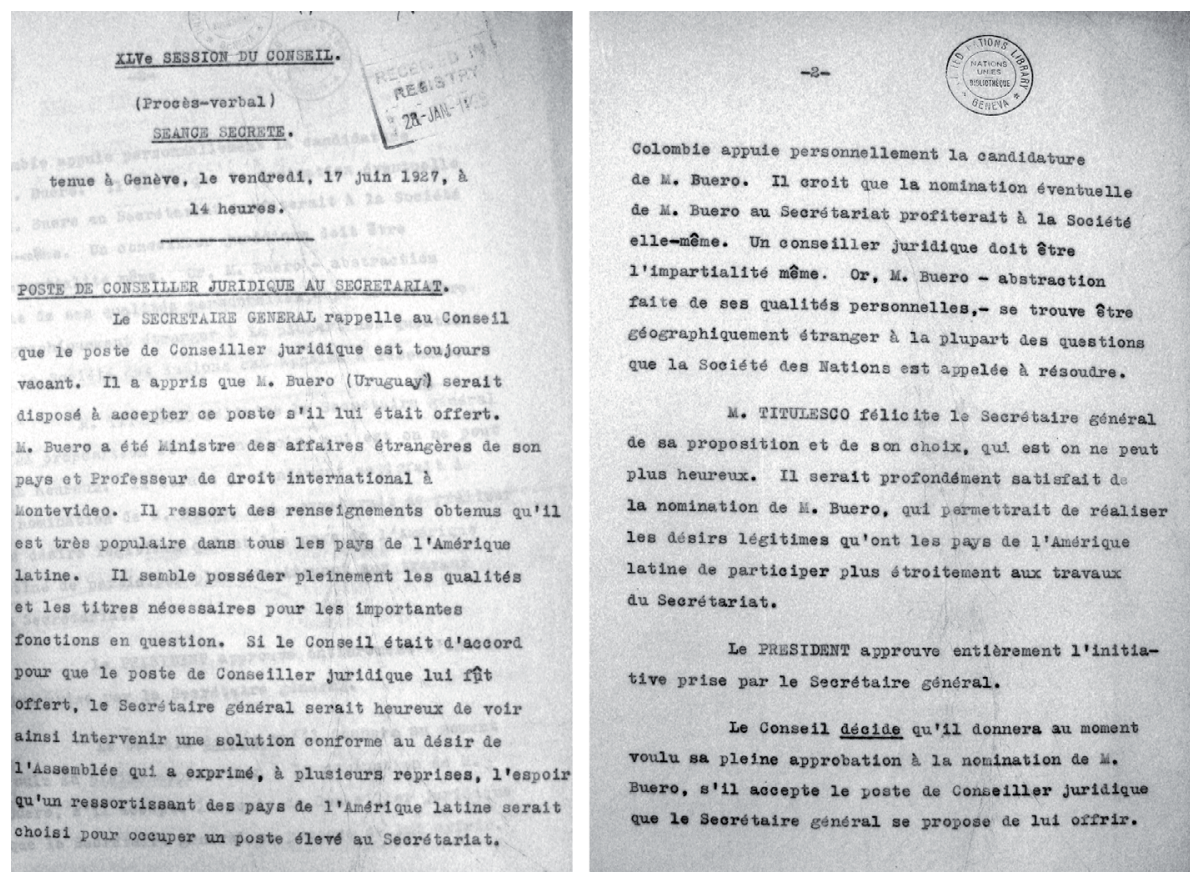

Il. 6. Czystopis kopii protokołu tajnego spotkania członków Rady bez asygnaty Sekretarza Generalnego

rza Generalnego, co robił zwyczajowo w innych przypadkach. Nie ulega też wątpliwości, że „nowa wersja” nie jest oryginałem, lecz kopią! Może inicjały E.D., którymi zwyczajowo sygnował Sekretarz Generalny przeczytane dokumenty, widnieją na oryginale? Jeśli tak, to nie tylko na oryginałach, większość bowiem protokołów udostępnianych czytelnikom w archiwum Ligi Narodów to kopie, które mają widemat Erica Drummonda jako jedynego ich korektora.

Omawiane i zaprezentowane powyżej dokumenty są w tym sensie nietypowe, że zwykle Sekretarz Generalny ograniczał ingerencje w protokół do spraw językowych, formalnych, bardziej poprawiając protokolanta niż osobę wypowiadającą się $\mathrm{w}$ danej kwestii. Z reguły nie dochodziło do wprowadzania zmian i poprawek przez zainteresowane osoby post factum. Praktyka ta miała miejsce wobec tekstów wystąpień na sesjach prywatnych czy nawet publicznych Rady, zanim przekazano je do druku. O wdrożenie tej praktyki także do spotkań tajnych upomniał się norweski min. Hambro 9 grudnia 1932 r., który chciał zapewnić tym protokołom „pełną wartość historyczną”. Dlatego osoby wypowiadające się, jeśli zechcą, powinny mieć możliwość sprawdzenia „prawidłowości swoich wypowiedzi”. Interwencja ta odniosła połowiczny skutek. Postanowiono bowiem, że protokoły z tajnych spotkań będą prze- 
chowywane tylko w jednym egzemplarzu, a członkowie Rady będą mogli zapoznać się z jego treścią, u szefa Documents Service ${ }^{25}$.

Widoczny brak konsekwencji wobec protokołów z tajnych spotkań członków Rady wynikał z ogólnego stosunku Sekretarza Generalnego do tej, stale nieformalnej aktywności Rady. Tajne spotkania mogły być uznane jako działania pomocnicze, zgodne z brytyjskim wyobrażeniem o Lidze jako clearing hause polityki międzynarodowej. Spotkania te miały służyć rozeznaniu sytuacji i odpowiedzi na pytanie: co w danej sprawie, będącej przedmiotem zainteresowania najbliższej Rady (Zgromadzenia), jest możliwe do osiągnięcia, jaka byłaby najlepsza procedura przy założeniu minimalizacji kosztów, zysków i strat. $\mathrm{W}$ tym rozumieniu protokoły $\mathrm{z}$ tajnych spotkań Rady nie były oficjalnymi dokumentami $\mathrm{Ligi}^{26}$, a jedynie odzwierciedlały zapatrywania poszczególnych państw, nieraz także tylko ich przedstawicieli, jak to bywało w przypadku delegatów z Ameryki Południowej. Nie dziwi przeto, że niektóre spotkania (zawsze odbywane w trakcie trwania oficjalnych sesji Rady!) przybierały charakter swoistego tors d'horizons w odniesieniu do wszystkich, a przynajmniej najważniejszych punktów przewidzianych do rozpatrzenia czy to na sesjach prywatnych, publicznych, czy na forum Zgromadzenia.

Pomocniczy, z formalnego punktu widzenia, prywatny charakter spotkań członków Rady powodował, że protokoły odzwierciedlające ich przebieg nie wchodziły do grupy oficjalnej dokumentacji LN. Z drugiej strony, każdy lub niemal każdy protokół z tajnych spotkań nosił poprawki dokonane ręką Sekretarza Generalnego (nieraz daleko idące w odniesieniu do własnych wypowiedzi, jak to pokazuje ilustracja nr 5) oraz podpis „E.D.” i datę. Urzędowy charakter tej dokumentacji podkreślają okrągłe pieczęcie znajdujące się w górnej części pierwszej strony protokołu. Na otoku pieczątki z epoki był napis: Société des Nations. League of Nations. Registry. Przed udostępnieniem dokumentacji LN w 1969 r. opieczętowano każdą ze stron pieczęcią okrągłą z napisem na otoku United Nations Library. Geneva. W środku pieczęci: Nations Unies. Bibliothèque. Zwykle w lewym górnym rogu strony pierwszej widniała informacja w formie pieczęci prostokątnej o treści: Action Copy. Received in Registry 28-Jan.-1929. Powyższe mówi, że we wskazanych wyżej dniach Archiwum (Registry et du Service des Index) przejęło te materiały z sekretariatu Sekretarza Generalnego.

${ }^{25}$ ASDN, 14/9885/2385, r. 6228. Minutes of the 5th Secret Meeting..., December 9th 1932 at 4 p.m.

26 Regulamin dotyczący zakresu działalności archiwum mówił, że było ono odpowiedzialne za rejestrację, zachowanie i klasyfikację oficjalnej korespondencji, wytworzonej lub przekazywanej przez Sekretariat. Do obowiązków archiwistów (około 20 osób w połowie lat dwudziestych) należało też indeksowanie dokumentów oraz ich obieg w ramach Sekretariatu. Archiwum sporządzało też codziennie wyciągi z zarejestrowanej korespondencji służbowej, zob. Annuaire de la Société des Nations 1919-1927, s. 87. 


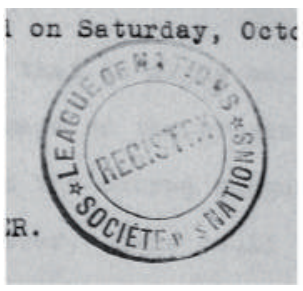

a

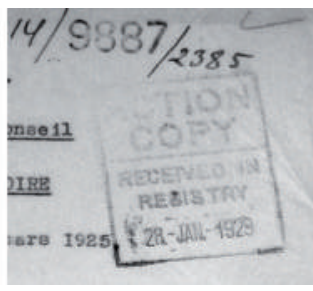

$\mathrm{b}$

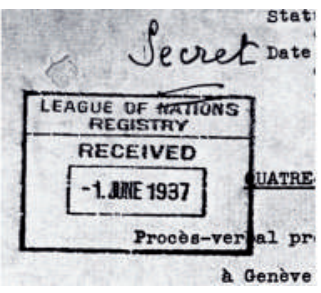

C

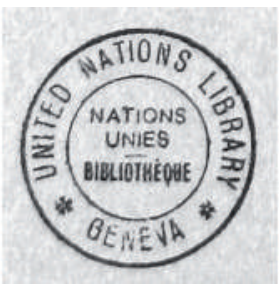

$\mathrm{d}$

Il. 7. Pieczęcie na protokołach z tajnych spotkań członków Rady potwierdzające ich przejęcie przez Archiwum (a - okrągła z epoki o średnicy $3 \mathrm{~cm}$; b, c - prostokątne o różnych wymiarach; d - okrągła o średnicy $2 \mathrm{~cm}$ poprzedzająca udostępnienie archiwaliów)

Inicjatywa ta wymusiła ustalenie procedury związanej z protokołami z tajnych spotkań Rady. Frank Walters, dyrektor biura Sekretarza Generalnego, informował szefa Archiwum, że protokoły „powinny być oczywiście całkowicie tajne". W poszczególnych sekcjach dopuszczano możliwość istnienia streszczeń niektórych spotkań ${ }^{27}$. W ślad za tym 4 kwietnia $1929 \mathrm{r}$. J. Vallery-Radot, szef Registry et du Service des Index, przekazał do sekretariatu Sekretarza Generalnego chronologiczny rejestr 27 spotkań od 25 lutego 1921 r. do 6 czerwca 1928 r. Niemal dziesięć lat później sporządzona została kolejna lista, różniąca się od pierwotnej, m.in. chronologią doprowadzoną do 15 stycznia $1930 \mathrm{r}$. Istotne jest to, że protokoły te, a także z lat 1931-1932 znalazły się pod wspólną sygnaturą, co odnotowane zostało w Repertoire Général 1919-1946: 14/9887/2385; r. 6228. W tym podstawowym dla kwerendy wykazie nie odnotowano informacji o miejscu protokołów z tajnych spotkań członków Rady za czasów Avenola, tj. w latach 1933-1939. Razem z Jacques'em Obersonem, przyjaznym dla badaczy pracownikiem archiwum ASDN, biedziłem się w czerwcu 2014 r. poszukiwaniem tej dokumentacji, w której korzystałem ćwierć wieku wcześniej. Nie pomogły zrobione wówczas kserokopie spisów owych posiedzeń Rady (około 70) ani nawet reprodukcje konkretnych protokołów, wówczas interesujących mnie wybiórczo. Po powrocie z wyprawy genewskiej, na podstawie posiadanej dokumentacji mogłem zlokalizować ten swoisty podzespół znajdujący się o kilka sygnatur dalej. Powiadomiony o "odkryciu” Jacques Oberson potwierdził 8 sierpnia 2014 r., że w ramach sekcji 6232 znajdują się poszukiwane dokumenty od 1 lutego 1933 r. do 9 grudnia 1939 r.

Trudności z dotarciem do protokołów z tajnych spotkań członków Rady sugerują, że w prowadzonych, jakże rozległych - w sensie liczbowym, terytorialnym i merytorycznym - badaniach nad działalnością LN, nie były (w ostatnich przynajmniej latach) wykorzystywane. Nie może to oznaczać,

${ }^{27}$ ASDN, 14/9887/2385; r. 6228; F. Walters do Registry, 14 marca 1929. 


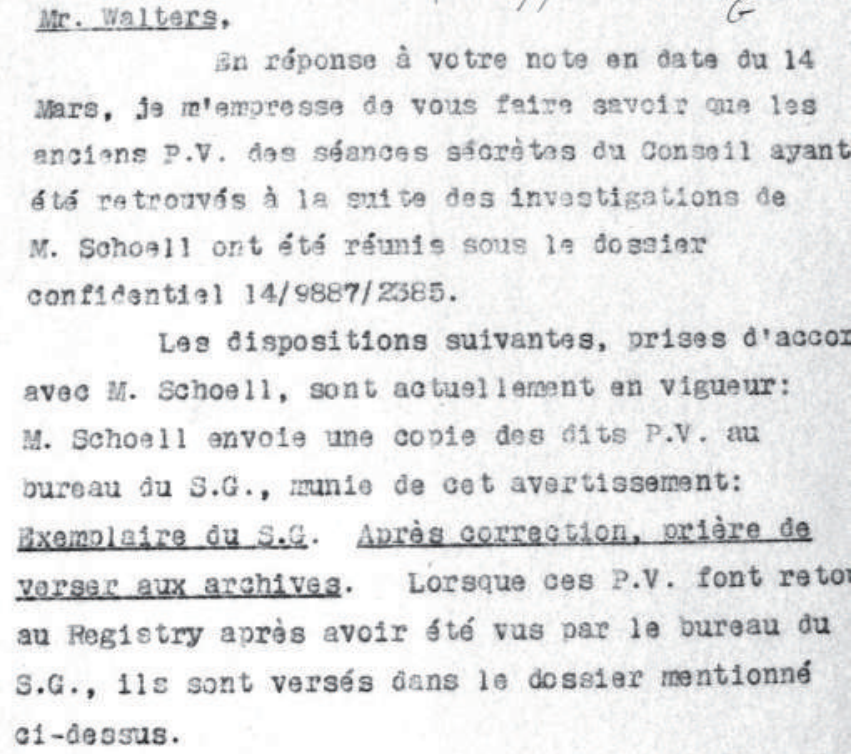

J. Vallery-Radot.

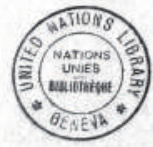

Thef du Registry et ô Serviee des Index. 16 Mars 1929.

Il. 8. Informacja szefa archiwum dla dyrektora Biura Sekretarza Generalnego z 29 marca 1929 r. dotycząca archiwizacji protokółów z tajnych spotkań członków Rady LN .

że dla rekonstrukcji i interpretacji funkcjonowania LN dokumentacja ta może być uznana za mniej ważną, podrzędną względem oficjalnych dokumentów tej organizacji. Dla nurtującej mnie gradacji co do odpowiedzialności poszczególnych państw za rozwój sytuacji międzynarodowej prowadzącej od „wielkiej wojny" do hekatomby drugiej światowej, protokoły ze „swobodnej” wymiany zdań najważniejszych państw świata (bez Stanów Zjednoczonych poza konfliktem o Mandżurię) mają dużą wartość. Dlatego nie może wchodzić w grę lekceważenie tej dokumentacji czy też pomijanie jej w badaniach. Trudności z dotarciem do tej dokumentacji za lata 1933-1939 sugerują, że tak właśnie jest. 


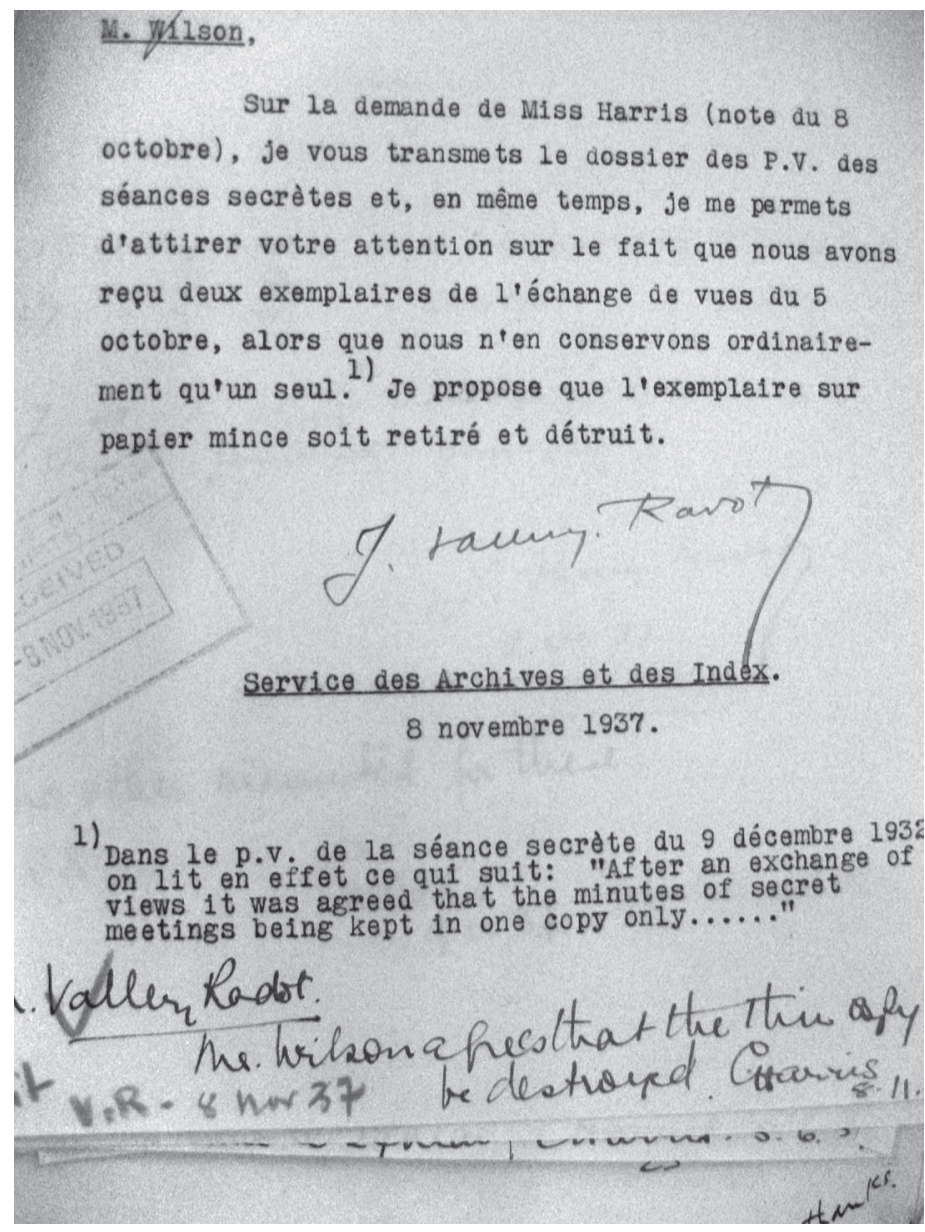

Il. 9. Przypomnienie z 8 listopada 1937 r., aby przechowywać tylko jeden egzemplarz, a kopie zniszczyć

Wartość tej dokumentacji (o różnej objętości, nieraz do kilkunastu stron maszynopisu) raczej rośnie $\mathrm{w}$ oczach badacza przez fakt, że wypowiadające się osoby zasadniczo nie miały możliwości wprowadzania korekt post factum. Kompetencje w tym zakresie zarezerwował dla siebie Sekretarz Generalny. Po jego korekcie, sprowadzającej się w odniesieniu do wypowiedzi osób trzecich do formalnych poprawek, protokół wracał do archiwum. Zwrócone z biura Sekretarza Generalnego dokumenty były włączane do tajnego dossier o sygnaturze 14/9887/2385. Pieczę nad nimi sprawował Franc-Luisa Schoell.

Temat wglądu w protokoły ze strony autorów wypowiedzi - jak o tym pisano wyżej - powracał, co jednak nie dawało efektu w postaci korekt/popra- 
wek naniesionych w wyniku interwencji któregoś z członków tajnego spotkania. Praktykę w tym zakresie przejął od sir Erica kolejny Sekretarz Generalny, który uległ dopiero w końcu okresu międzywojennego: od 1938 r. uczestnicy tajnych spotkań Rady mieli 24 godziny na naniesienie korekty. Korzystali $\mathrm{z}$ tego $\mathrm{w}$ bardzo ograniczonym stopniu, chociaż do wybuchu wojny odbyło się 20 takich spotkań, ostatnie 9 grudnia. Nazywano je: échange de vues ${ }^{28}$.

Poczynając od swoistej „rewolucji biurowo-archiwalnej” z wiosny 1929 r., kiedy sekretariat Sekretarza Generalnego i Archiwum podjęły próbę uregulowania sytuacji zawieszonych $\mathrm{w}$ próżni protokołów z tajnych spotkań członków Rady, spływały one sukcesywnie do Archiwum, jakkolwiek nie na wszystkich odnotowano datę przejęcia. Nie była to ani jedyna, ani najważniejsza niedoskonałość obiegu dokumentów. Znacznie bardziej widoczna jest obecność (w różnych nieraz miejscach) kopii tychże protokołów. Nie zainteresowało mnie, czy były to kopie powstałe przed korektą Sekretarza Generalnego, czy po niej. Niewątpliwie, jak widać na ilustracjach nr 5 i 6, poprawione wersje protokołów były przepisane. Możliwe, że tak postępowano również z innymi protokołami, nadając im status pierwopisu (oryginału). W badanym dossier, odnoszącym się do lat 1921-1932 "pierwopisów" nie było w ogóle albo były nieliczne ${ }^{29}$. Problem był obecny przez cały czas tajnych spotkań Rady, które zawsze były obarczone krytyką nieobecnych lub z jakichś powodów pominiętych. Skrywanie treści (w tym napiętnowanie „przecieków") znajdowało odzwierciedlenie w często powracającej sprawie ",jednego egzemplarza". Jakkolwiek - jak to już wiadomo - celu tego nie osiągnięto, to jednak do kwestii tej wracano kilkakrotnie.

Podczas tajnego spotkania 9 grudnia 1932 r. ustalono, że protokoły z tych narad będą przechowywane w jednym egzemplarzu (zob. ilustracje nr 8 i 9). Praktyka była odmienna, co potwierdziła przeprowadzona ostatnio kwerenda w ASDN za lata 1921-1932. W notatce J.V. Wilsona z sekretariatu Sekretarza Generalnego, przekazanej do p. Harris z Archiwum, zauważono, że istniały dwa egzemplarze protokołów „wymiany opinii” z 5 października 1937 r. Przypominano, że egzemplarz ma być jeden, a "kopię na cienkim papierze należy usunąć i zniszczyć" ${ }^{\prime 30}$.

W badanych w 2014 r. źródłach ASDN w zakresie tajnych spotkań członków Rady LN za lata 1921-1932 oraz w 1990 r. także (choć niezbyt dokładnie) zwróciłem uwagę na istnienie kopii tych protokołów, nieraz kolejnych, nawet utrudniających lekturę. Oryginałów nie pamiętam. Chociaż wydaje

28 ASDN, 14/3593/1198; r. 6232. Procès verbaux des Séances secrètes du Conseil, dok. bez daty.

${ }^{29}$ Aparat cyfrowy wykorzystywany do kopiowania tych dokumentów także post factum pozwala na stwierdzenie, czy mamy oryginał czy kopię.

30 ASDN, 14/9887/2385; r. 6232; Service des Archives et des Index, 8 novembre 1937 (Notatka J.Valery-Radot'a do J.V. Wilsona). 


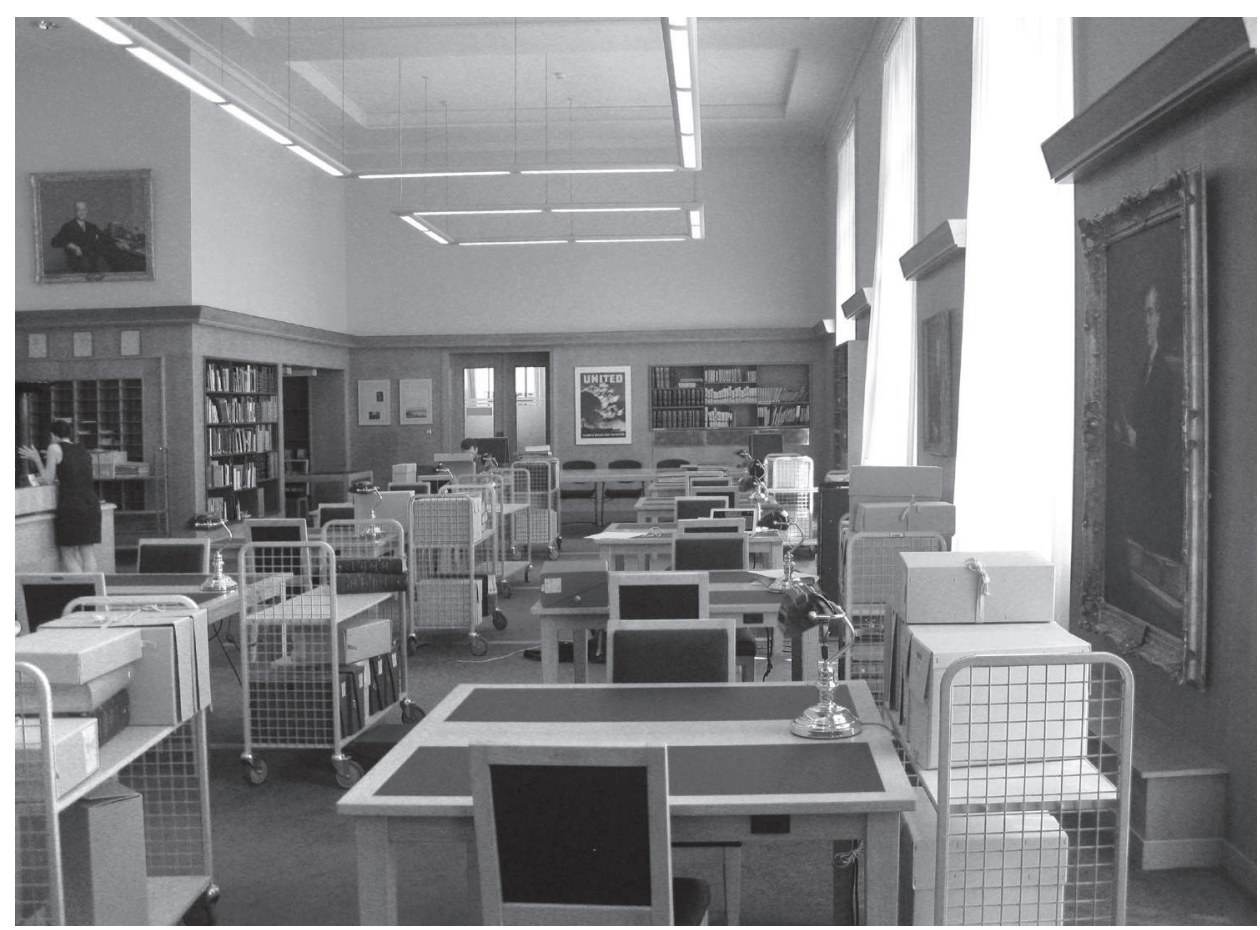

Il. 10. Widok na czytelnię Archiwum Ligi Narodów i ONZ w Palais des Nations w Genewie

się to mało prawdopodobne, to jednak przekazywane w okresie międzywojennym pewne dokumenty do "skarbca biblioteki" ${ }^{31}$ (nieraz wcale nie takich ważnych) nadal tam zalegają. W odniesieniu do protokołów tajnych spotkań członków LN nie miałoby to żadnego merytorycznego uzasadnienia. Także dlatego, że dla badaczy kopie wystarczają jako materiał pomocniczy dla poznania działalności LN. Dla wniknięcia w ligowe zakamarki stanowią źródło o pierwszorzędnej wadze.

${ }^{31}$ Dossiers secrets gardés à la chambre forte de la bibliothèque. 


\title{
Stanisław Sierpowski \\ Tajne spotkania członków Rady Ligi Narodów w świetle dokumentacji Archivès de la Société des Nations w Genewie
}

\begin{abstract}
Streszczenie
W artykule zostało uwypuklone znaczenie dokumentacji archiwalnej z poufnych lub tajnych spotkań lub „wymiany zdań” członków Rady LN, podczas których wykuwały się lub były ustalone rozwiązania prezentowane następnie podczas "prywatnych" lub „publicznych" sesji. Zwrócenie uwagi na rolę tej dokumentacji dla poznania polityki poszczególnych państw reprezentowanych $w$ Radzie jest poza dyskusją. Nie wydaje się jednak, aby badacze dziejów LN, a więc i pośrednio stosunków międzynarodowych okresu międzywojennego, przywiązywali wagę do tej spuścizny. Pośrednio świadczą o tym trudności z dotarciem do sporządzanych na bieżąco protokołów, które za lata 1933-1939 nie są ujęte w Archives de la Société des Nations 1919-1946. Répertoire Général 1919-1946, (Genève sd., s. 664). Z dokumentacji tej - bardziej niż z innej - wyziera dominacja interesu własnego, aczkolwiek przyodzianego w "ligowe szaty". Tajne spotkania członków Rady, mające pierwotnie na celu uzgodnienie stanowiska w kwestiach personalnych, przybrały charakter narady o najważniejszych, zwłaszcza konfliktowych problemach widniejących $\mathrm{w}$ programie sesji publicznych. Tym ostatnim nadawano szeroki rozgłos, w przeciwieństwie do narad tajnych, które kłóciły się z filozofią Ligi Narodów, wyrażoną także w preambule do Paktu, gdzie zakładano „utrzymywanie jawnych stosunków międzynarodowych".
\end{abstract}

\section{Secret meetings of the members ot the Council League of Nations, as presented in the documents of Archivès de la Sociéte des Nations in Geneva}

\begin{abstract}
The article emphasizes how important the archive documents drafted during secret or confidential meetings (or "exchange of opinions" sessions) of the members of the Council League of Nations are. During these sessions, the solutions subsequently presented during "private" or "public" sessions were developed. The role of these documents for understanding the policies of individual states represented in the Council is indisputable. It does not seem, however, that the researchers of the history of the League, and so indirectly the researchers of the international relations of the period 1918-1939, paid enough attention to this heritage. Indirectly, it is evidenced by the difficulties with accessing protocols drafted during these sessions, of which protocols for the years 1933-1939 are not included in the Archives de la Société des Nations 1919-1946. Répertoire Général 1919-1946, (Genève sd. p. 664). These documents - more than any others - prove than individual interests dominated, although they were disguised as the interests of the League. Secret meetings of the members of the Council were initially supposed to coordinate the positions on personal matters. However, they turned into debates about the most pivotal, especially conflictual problems present in the agenda of the public sessions. Those agendas were then highly publicized, as opposed to the agendas of the secret meetings - the fact which contradicted the philosophy of the League, which was also expressed in the Preamble to the Treaty, where sustaining transparent international relations was assumed.
\end{abstract}

